PACS numbers: 87.23._n, 89.60._k , 07.88._y

\title{
MODELLING AND FORECASTING THE HYDROECOLOGICAL SYSTEMS POLLUTION DYNAMICS BY USING A CHAOS THEORY METHODS: II. ADVANCED CHAOS DATA ON POLLUTION OF THE SMALL CARPATHIANS RIVER'S WATERSHEDS
}

\author{
A.V. Glushkov, Dr Sci. (Phis-Math.), \\ O.Yu. Khetselius, Dr Sci. (Phis-Math.), \\ N.G. Serbov, Cand. Sci. (Geogr.), \\ Yu.Ya. Bunyakova, Cand. Sci. (Geogr.), \\ V.V. Buyadzhi, E.P. Solyanikova \\ Odessa State Environmental University, 15 , \\ Lvivska St., 65016 Odessa, Ukraine, glushkovav@gmail.com
}

\begin{abstract}
This paper goes on our advanced quantitative studying results of a pollution dynamics for variations hydroecological systems, namely, the nitrates etc concentrations dynamics for a number of the Small Carpathians river's watersheds in the Eastern Slovakia. The different methods and algorithms of the chaos theory (chaos-geometric approach) and dynamical systems theory have been used in the advanced versions. New more exact data on chaotic behaviour of the nitrates concentration time series in the watersheds of the Small Carpathians are presented. In previous paper [1] to reconstruct the corresponding attractor, the time delay and embedding dimension have been needed and computed. The parameters are determined by the methods of autocorrelation function and average mutual information. Besides, there are used the advanced versions of the correlation dimension method and algorithm of false nearest neighbours. The Fourier spectrum of the concentration of nitrates in the water catchment area Ondava: Stropkov for the period 1969-1996 is listed. Here we present new advanced data on the correlation dimension $\left(\mathrm{d}_{2}\right)$, embedding dimension $\left(d_{\mathrm{E}}\right)$, Kaplan-Yorke dimension $\left(d_{\mathrm{L}}\right)$, average limit of predictability $\left(P r_{\max }\right)$ and parameter $K$ for the nitrates concentrations in the watersheds of the Small Carpathians.
\end{abstract}

Key words: hydroecological systems dynamics, studying and forecasting, nitrates and sulphates

concentrations, the Small Carpathians river's watersheds, chaos theory methods

\section{INTRODUCTION}

This paper goes on our advanced quantitative studying results of a pollution dynamics for variations hydroecological systems, namely, the nitrates etc concentrations dynamics for a number of the Small Carpathians river's watersheds in the Eastern Slovakia. The different methods and algorithms of the chaos theory (chaosgeometric approach) and dynamical systems theory have been used in the advanced versions. New more exact data on chaotic behaviour of the nitrates concentration time series in the watersheds of the Small Carpathians are presented. In previous paper [1] to reconstruct the corresponding attractor, the time delay and embedding dimension have been needed and computed. The parameters are determined by the methods of autocorrelation function and average mutual information. Besides, there are used the advanced versions of the correlation dimension method and algorithm of false nearest neighbours. The Fourier spectrum of the concentration of nitrates in the water catchment area Ondava: Stropkov for the period 1969 - 1996 is listed.

As usually let us remind that many studies in various fields of science have appeared, where chaos theory was applied to a great number of systems [1-14]. The studies concerning non-linear behaviour in the time series of atmospheric constituent concentrations are sparse, and their outcomes are ambiguous. In refs. [5,6] there is an analysis of the $\mathrm{NO}_{2}, \mathrm{CO}, \mathrm{O}_{3}$ concentrations time series and is not received an evidence of chaos. In refs. [2, $10,12]$ there is an analysis of the $\mathrm{NO}_{2}, \mathrm{CO}, \mathrm{O}_{3}$ concentra- tions time series in the Gdansk and Trieste region and it has been definitely received the same. These studies show that chaos theory methodology can be applied and the short-range forecast by the non-linear prediction method can be satisfactory. It opens very attractive perspectives using the same methods in studying dynamics of pollution of other ecological and hydrological systems.

In this work we go on studying the pollutions dynamics of the hydrological systems, in particular, variations of the nitrates concentrations in the river's water reservoirs in the Earthen Slovakia [11,12] by using the nonlinear prediction approaches and chaos theory method (in versions) [1-5,13-20]. Here we present new advanced data on the correlation dimension $\left(\mathrm{d}_{2}\right)$, embedding dimension $\left(d_{\mathrm{E}}\right)$, Kaplan-Yorke dimension $\left(d_{\mathrm{L}}\right)$, average limit of predictability $\left(P r_{\max }\right)$ and parameter $K$ for the nitrates concentrations in the watersheds of the Small Carpathians.

\section{CHAOS IN TIME SERIES OF CONCENTRATIONS}

\subsection{The input data}

As the initial data we use the results of empirical observations made on six watersheds (fig.1)in the region of the Small Carpathians, carried out by co-workers of the Institute of Hydrology of the Slovak Academy of Sciences [21,22]. Fig.2 shows the temporal changes in the concentrations of nitrates in the catchment areas. Table 1 presents some of the important statistics (coordinates of 
sites 6 and 9 are $54^{\circ} 24^{\prime} 54^{\prime \prime} \mathrm{N}, 18^{\circ} 34^{\prime} 47^{\prime \prime} \mathrm{E}$ and $\left.54^{\circ} 29^{\prime} 40^{\prime \prime} \mathrm{N}, 18^{\circ} 33^{\prime} 15^{\prime \prime} \mathrm{E}\right)$ [2]. In fig. 3 we list the Fourier spectrum of the concentration of nitrates in the water catchment area Ondava: Stropkov for the period 1969 1996. The X-axis - frequency, the axis $\mathrm{Y}$ - energy. The

As usually, we consider scalar measurements $s(n)=s\left(t_{0}+n \Delta t\right)=s(n)$, where $t_{0}$ is a start time, $\Delta t$ is time step, and $n$ is number of the measurements. In a general case, $s(n)$ is any time series (f.e. pollutants concentra- tion). As processes resulting in a chaotic behaviour are fundamentally multivariate, one needs to reconstruct phase space using as well as possible information contained in $s(n)$. Such reconstruction results in set of $d$ dimensional vectors $\mathbf{y}(n)$ replacing scalar measurements. The main idea is that direct use of lagged variables $s(n+\tau)$, where $\tau$ is some integer to be defined, results in a coordinate system where a structure of orbits in phase.

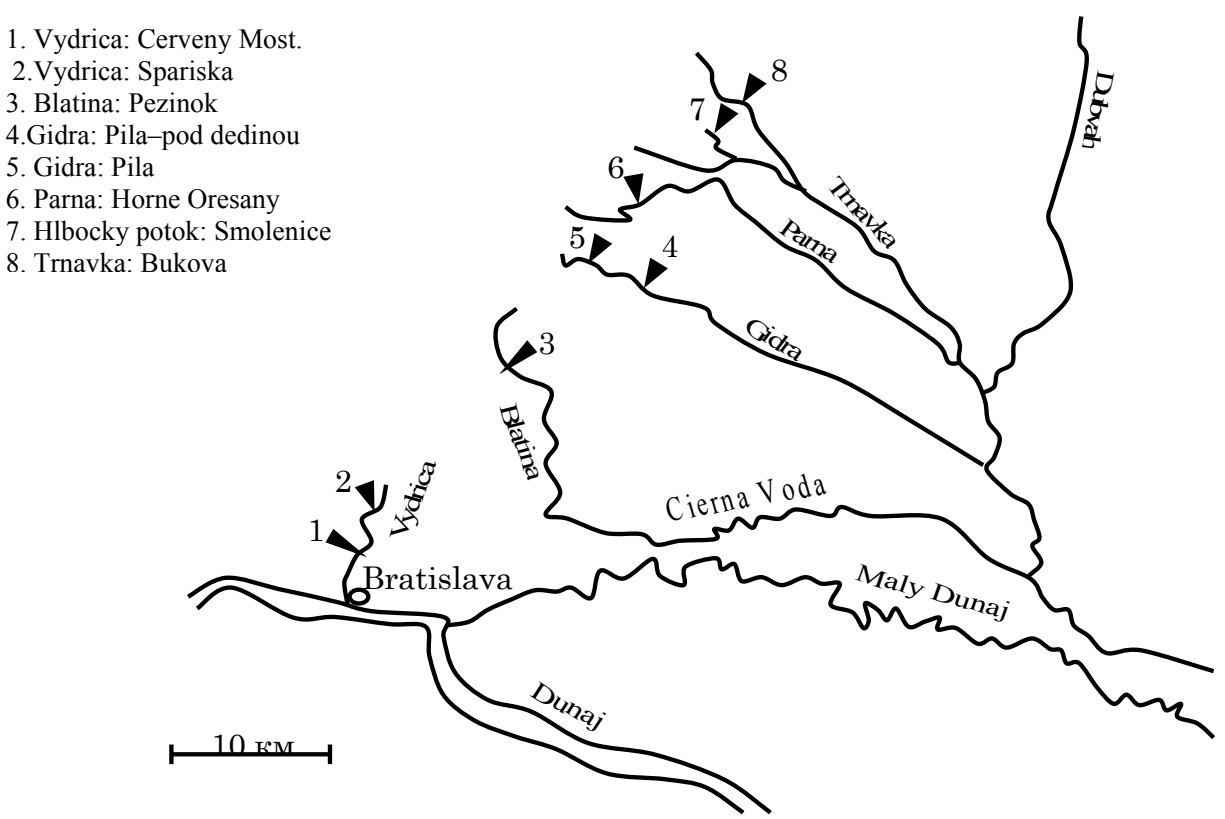

Fig. 1 - Scheme of the observation points in the Small Carpathians (Slovakia) (see text).
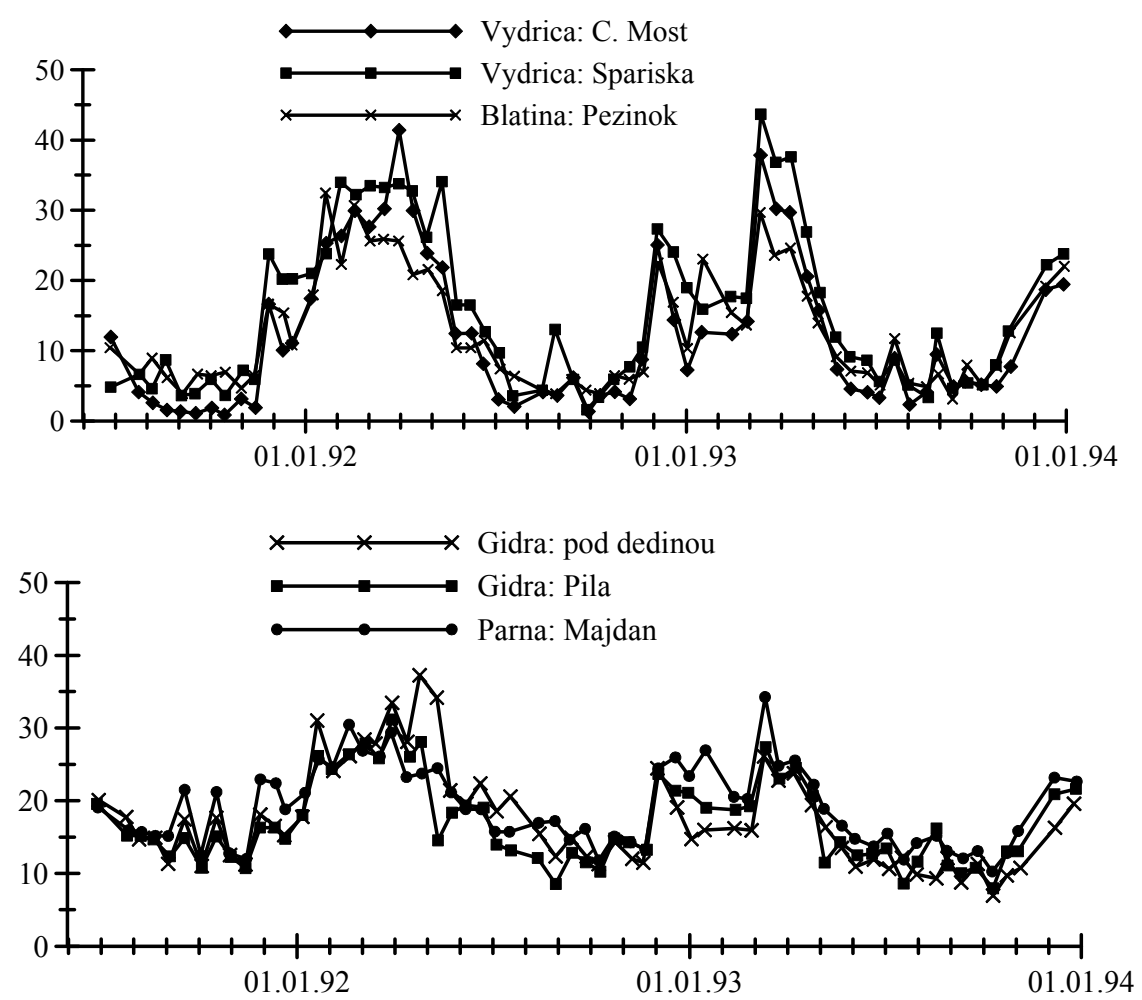

Fig. 2 - The temporal changes in the concentrations of nitrates in some catchment of the Small Carpathians (Slovakia) [2]. 


\subsection{Advanced computing results}

In Ref. [1] we have the time delay, embedding dimension and other parameters by the methods of autocorrelation function and average mutual information as well as the advanced versions of the correlation dimension method and algorithm of false nearest neighbours. We have listed the Fourier spectrum of the concentration of nitrates in the water catchment area Ondava: Stropkov for the period 1969 - 1996. Using these results, further we have computed the correlation dimension $\left(\mathrm{d}_{2}\right)$, embedding dimension $\left(d_{\mathrm{E}}\right)$, Kaplan-Yorke dimension $\left(d_{\mathrm{L}}\right)$, aver age limit of predictability $\left(P r_{\max }\right)$ and parameter $K$ for the nitrates concentrations in in the watersheds of the Small Carpathians. The corresponding data are listed in the
Table 1. We also note that the length and discrete time series in Table 1 are different, namely, for the first time series time step of 1 month to the next five - half a month, and for the last four - one night; $\tau$ and $P r_{\max }$ have the corresponding dimensions. As it is indicated, the sum of the positive Lyapunov's exponents $\lambda_{\mathrm{i}}$ determines the Kolmogorov entropy, which is inversely proportional to the limit of predictability $\left(P r_{\max }\right)$. Let us remind since the conversion rate of the sphere into an ellipsoid along different axes is determined by the $\lambda_{\mathrm{i}}$, it is clear that the smaller the amount of positive dimensions, the more stable is a dynamic system.

Table 1 - Time lag $(\tau)$, correlation dimension $\left(\mathrm{d}_{2}\right)$, embedding dimension $\left(d_{\mathrm{E}}\right)$, Kaplan-Yorke dimension $\left(d_{\mathrm{L}}\right)$, average limit of predictability $\left(P r_{\max }\right)$ and parameter $K$ for the nitrates concentrations in in the watersheds of the Small Carpathians (see text)

\begin{tabular}{|l|l|l|l|l|r|l|}
\hline River (Site) & $\tau$ & $d_{2}$ & $d_{E}$ & $d_{L}$ & $P r_{\max }$ & $K$ \\
\hline Vydrica (C.Most) & 19 & 5,22 & 6 & 5,03 & 12 & 0,71 \\
\hline Vydrica (Spariska) & 18 & 5,67 & 6 & 5,86 & 13 & 0,66 \\
\hline Blatina (Pezinok) & 18 & 4,93 & 5 & 5,03 & 13 & 0,69 \\
\hline Gidra (Main) & 16 & 5,14 & 6 & 5,88 & 14 & 0,82 \\
\hline Gidra (Pila) & 20 & 5,81 & 6 & 5,18 & 12 & 0,75 \\
\hline Pama (Majdan) & 18 & 4,18 & 5 & 4,82 & 12 & 0,66 \\
\hline
\end{tabular}

The presence of the two (from six) positive $\lambda_{i}$ suggests the system broadens in the line of two axes and converges along four axes that in the six-dimensional space. Our data show that the greatest degree of predictability is observed for the time series of nitrates in the watershed Gidra (Main) (fourteen slots, i.e. seven months), and in other cases the limit of predictability is slightly less. Such predictability is quite sufficient for the prediction of pollution.

\section{NONLINEAR PREDICTION MODEL}

First of all, it's important to define how predictable is a chaotic system? The predictability can be estimated by the Kolmogorov entropy, which is proportional to a sum of the positive Lyapunov's exponents. The spectrum of Lyapunov's exponents is one of dynamical invariants for non-linear system with chaotic behaviour. The limited predictability of the chaos is quantified by the local and global Lyapunov's exponents, which can be determined from measurements. The Lyapunov's exponents are related to the eigen values of the linearized dynamics across the attractor. Negative values show stable behaviour while positive values show local unstable behaviour. For chaotic systems, being both stable and unstable, Lyapunov's exponents indicate the complexity of the dynamics. The largest positive value determines some average prediction limit. Since the Lyapunov's exponents are defined as asymptotic average rates, they are independent of the initial conditions, and hence the choice of trajectory, and they do comprise an invariant measure of the attractor. An estimate of this measure is a sum of the positive Lyapunov's exponents. The estimate of the attractor dimension is provided by the conjecture $d_{L}$ and the Lyapunov's exponents are taken in descending order. The dimension $d_{L}$ gives values close to the dimension estimates discussed earlier and is preferable when estimating high dimensions. To compute Lyapunov's exponents, we use a method with linear fitted map [1,2], although the maps with higher order polynomials can be used too. The sum of positive Lyapunov's exponents determines the Kolmogorov entropy, which is inversely proportional to the limit of predictability $\left(P r_{\max }\right)$.

\section{CONCLUSSIONS}

In first part of the paper we present renewed quantitative studying results for the nitrates concentrations dynamics for a number of the Small Carpathians river's watersheds in the Earthen Slovakia. The different methods and algorithms of the chaos theory (chaos-geometric approach) and dynamical systems theory have been used in the advanced versions. New more exact data on chaotic behaviour of the nitrates concentration time series in the watersheds of the Small Carpathians are presented. To reconstruct the corresponding attractor, the time delay and embedding dimension are needed. We have presented present the combined and final data on the time lags $(\tau)$, correlation dimensions $\left(d_{2}\right)$, embedding dimensions $\left(d_{\mathrm{E}}\right)$, Kaplan-Yorke dimensions $\left(d_{\mathrm{L}}\right)$, average limits of predictability $\left(P r_{\max }\right)$ and the known chaos parameter $K$ for the 
nitrates and sulphates concentrations time series in the watersheds of the Small Carpathians. On the basis of the advanced data we have definitely demonstrated the lowdimensional chaos in investigated time series, consider the advanced prediction model.

\section{REFERENCES}

1. Glushkov A.V., Khetselius O.Yu., Bunyakova Yu.Ya., Prepelitsa G.P., Solyanikova E.P., Serga E.N. Non-linear prediction method in short-range forecast of atmospheric pollutants: lowdimensional chaos. Dynamical Systems - Theory and Applications. Łódź, Poland, 2011, no. LIF111, pp. 1-6.

2. Glushkov A.V., Kuzakon' V.M., Khetselius O.Yu., Prepelitsa G.P., Svinarenko A.A., Zaichko P.A. Geometry of Chaos: Theoretical basis's of a consistent combined approach to treating chaotic dynamical systems and their parameters determination. Proceedings of International Geometry Center, 2013, no. 6 (1), pp. 43-48.

3. Glushkov A.V., Kuzakon' V.M., Khetselius O.Yu., Bunyakova Yu.Ya., Zaichko P.A., Geometry of Chaos: Consistent combined approach to treating chaotic dynamics atmospheric polutants and its forecasting. Proceedings of International Geometry Center, 2013, no. 6 (3), pp. 6-13.

4. Glushkov A.V., Serbov N.G., Svinarenko A.A., Buyadzhi V.V. Chaos-geometric analysis of time series of concentrations of sulphur dioxide in the atmosphere of the industrial city (on example of the Gdansk region. Ukr. gidrometeorol. ž.- Ukranian hydrometeorological journal, 2014, no.15, pp.238-241.

5. Glushkov A.V., Khokhlov V.N., Tsenenko I.A. Atmospheric teleconnection patterns: wavelet analysis. Nonlinear Processes in Geophysics, 2004, no. 11(3), pp. 285-293.

6. Khokhlov V.N., Glushkov A.V., Loboda N.S, Bunyakova Yu.Ya. Short-range forecast of atmospheric pollutants using non-linear prediction method. Atmospheric Environment (Elsevier), 2008, no. 42 , pp. 1213-1220.

7. Khokhlov V.N., Glushkov A.V., Loboda N.S., Serbov N.G., Zhurbenko K. Signatures of low-dimensional chaos in hourly water level measurements at coastal site of Mariupol, Ukraine. Stoch Environ Res Risk Assess (Springer), 2008, no. 22 (6), pp. 777-788.

8. Bunyakova Yu.Ya., Glushkov A.V. Analysis and forecast of the impact of anthropogenic factors on air basein of an industrial city. Odessa: Ecology, 2010. 256 p.

9. Glushkov A.V., Khokhlov V.N., Serbov N.G., Bunyakova Yu.Ya., Balan A.K., Balanyuk E.P. Low-dimensional chaos in the time series of concentrations of pollutants in an atmosphere and hydro- sphere. Visn. Odes. derž. ekol. univ.-Bulletin of Odessa state environmental university, 2007, no.4, pp.337-348.

10. Glushkov A.V. Analysis and forecast of the anthropogenic impact on industrial city's atmosphere based on methods of chaos theory: new general scheme. Ukr. gìdrometeorol. $̌$. - Ukranian hydrometeorological journal, 2014, no.15, pp.32-36.

11. Serbov N.G., Khetselius O.Yu., Balan A.K., Dudinov A.A. Prediction of chaotic processes in hydro systems based on the concept of attractor neural network and campaign. Ukr. gidrometeorol. $\check{z}$.- Ukranian hydrometeorological journal, 2013,.no.13, pp.86-91.

12. Serbov N.G., Balan A.K., Solyanikova E.P. Multivariate system and multifractal approaches in modeling extreme high floods (for example, Danube river) and temporal fluctuations in the concentrations of pollutants in the river water. Visn. Odes. derž. ekol. univ.-Bulletin of Odessa state environmental university, 2008, no.6, pp.7-13.

13. Kennel M.B., Brown R., Abarbanel H. Determining embedding dimension for phase-space reconstruction using a geometrical construction. Physical Review A., 1992, no. 45, pp. 3403-3411.

14. Pekarova P., Miklanek P., Konicek A., Pekar J. Water quality in experimental basins. National Report 1999 of the UNESKO.Project 1.1.-Intern.Water Systems, 1999, pp. 1-98.

15. Glushkov A.V. Methods of a chaos theory. Odessa: Astroprint, 2012.

16. Gallager R.G. Information theory and reliable communication. New-York, Wiley, 1986.

17. Lanfredi M., Macchiato M. Searching for low dimensionality in air pollution time series. Europhysics Letters 1997, 1997, pp. 589-594.

18. Koçak K., Şaylan L., Şen O. Nonlinear time series prediction of O3 concentration in Istanbul. Atmospheric Environment (Elsevier), 2000, no. 34, pp. 1267-1271.

19. Grassberger P., Procaccia I. Measuring the strangeness of strange attractors. Physica D., 1983, no. 9, pp. 189-208.

20. Gottwald G.A., Melbourne I. A new test for chaos in deterministic systems. Proc. Roy. Soc. London. Ser. A, Mathemat. Phys. Sci., 2004, no. 460, pp. 603-611.

21. Svoboda A., Pekarova P., Miklanek P. Flood hydrology of Danube between Devin and Nagymaros in Slovakia. Nat. Rep.2000, UNESKO.-Project 4.1.-Intern.Water Systems. 2000. 96 p.

22. Pekarova P., Miklanek P., Konicek A., Pekar J. Water quality in experimental basins. Nat. Rep.1999 of the UNESKO.-Project 1.1.Intern.Water Systems. 1999. 98 p.

\title{
МОДЕЛЮВАННЯ ТА ПРОГНОЗУВАННЯ ДИНАМІКИ ЗАБРУДНЕННЯ ГІДРОЕКОЛОГІЧНИХ СИСТЕМ ЗА ДОПОМОГОЮ МЕТОДІВ ТЕОРІЇ ХАОСУ: І. УТОЧНЕНІ ДАНІ ЩОДО ЗАБРУДНЕННЯ ВОДОДІЛІВ РІЧОК МАЛИХ КАРПАТ
}

\author{
О.В. Глушков, д.ф.-м.н., \\ О.Ю. Хецеліус, , д.ф.-м.н., \\ М.Г. Сербов, к.геогр.н., \\ Ю.Я. Бунякова, к. геогр.н., ст.викл., \\ Б.Б. Буяджи, викл. О.П.Соляникова
}

Одеський державний екологічний університет,

вул. Львівська, 15, 65016 Одеса, Україна, glushkovav@gmail.com

Ця робота продовжує наші уточнені кількісні дослідження динаміки забруднення різних гідроекологічних систем, зокрема, часової динаміки зміни концентрацій нітратів у ряді вододілів річок 
Малих Карпат у Східній Словаччині. Різні методи і алгоритми теорії хаосу (хаос-геометричного підходу) і теорії динамічних систем використані у найбільш досконалих версіях. Представлено нові більш точні дані, що характеризують хаотичну поведінку часових рядів концентрацій нітратів i сульфатів для ряду вододілів річок Малих Карпат. У попередніх роботах (див. [1]) для відновлення відповідного аттрактора, попередньо обчислювалися час затримки (часовий лаг) і розмірності вкладення. Параметри були визначені з використанням методів автокореляційної функції та середньої взаємної інформації. Крім того, були застосовані більш досконалі версії методу кореляційної розмірності і алгоритму помилкових найближчих сусідів. Представлено також розрахований спектр Фур'є концентрації нітратів для водозбору Ондава-Стропков за період 1969-1996рр. Також наведені нові більш точні результати по кореляційній розмірності $\left(\mathrm{d}_{2}\right)$, розмірності вкладення $\left(\mathrm{d}_{\mathrm{E}}\right)$, розмірності Каплан-Йорка $\left(\mathrm{d}_{\mathrm{L}}\right)$, середній межі передбачуваності $\left(\mathrm{Pr}_{\max }\right)$ і параметру хаосу К для концентрацій нітратів для ряду вододілів.

Ключові слова: гідроекологічні динамічні системи, вивчення та прогнозування, нітрати і сульфати концентрації, вододіли Малих Карпат, методи теорії хаосу

\title{
МОДЕЛИРОВАНИЕ И ПРОГНОЗИРОВАНИЕ ДИНАМИКИ ЗАГРЯЗНЕНИЯ ГИДРОЭКОЛОГИЧЕС- КИХ СИСТЕМ С ИСПОЛЬЗОВАНИЕМ МЕТОДОВ ТЕОРИИ ХАОСА: І. УТОЧНЕННЫЕ ДАННЫЕ ПО ДИНАМИКЕ ЗАГРЯЗНЕНИЯ ВОДОРАЗДЕЛОВ РЕК МАЛЫХ КАРПАТ
}

\author{
А.В. Глушков, д.ф.-м.н., \\ О.Ю. Хецелиус, д.ф.-м.н., \\ Н.Г. Сербов, к.геогр.н., \\ Ю.Я. Бунякова, к.геогр.н., ст.преп., \\ Б.Б. Буяджи, преп. Е.П.Соляникова \\ Одесский государственный экологический университет, \\ ул. Львовская,15 ,65016, Одесса, Украина, glushkovav@gmail.com
}

\begin{abstract}
Данная работа продолжает наши уточненные количественные исследования динамики загрязнения различных гидроэкологических систем, в частности, временной динамике изменения концентраций нитратов в ряде водоразделов рек Малых Карпат в Восточной Словакии. Различные методы и алгоритмы теории хаоса (хаос-геометрического подхода) и теории динамических систем использованы в наиболее совершенных версиях. Представлены новые более точные данные, характеризующие хаотическое поведение временных рядов концентраций нитратов для ряда водоразделов рек Малых Карпат. В предыдущих работах (см.[1]) для восстановления соответствующего аттрактора, предварительно вычислялись время задержки (временной лаг) и размерности вложения. Искомые параметры определялись с использованием методов автокорреляционной функции и средней взаимной информации. Кроме того, были применены более совершенные версии метода корреляционной размерности и алгоритма ложных ближайших соседей. Представлен также рассчитанный спектр Фурье концентрации нитратов для водосбора Ондава-Стропков за период 1969-1996гг. Здесь мы приводим новые более точные результаты по корреляционной размерности $\left(\mathrm{d}_{2}\right)$, размерности вложения $\left(\mathrm{d}_{\mathrm{E}}\right)$, размерности Каплан-Йорка $\left(\mathrm{d}_{\mathrm{L}}\right)$, среднему пределу предсказуемости $\left(\mathrm{Pr}_{\max }\right)$ и параметру хаоса $\mathrm{K}$ для концентраций нитратов для ряда водоразделов.
\end{abstract}

Ключевые слова: гидроэкологические динамические системы, изучения и прогнозирования, нитраты и сульфаты концентрации, водоразделы рек Малых Карпат, методы теории хаоса 